\title{
Seroepidemiology of human fascioliasis and its relationship with anti-Fasciola IgG and liver enzymes as biomarkers of pathogenicity
}

\author{
Kiran Afshan ${ }^{1}$, Saman Kabeer ${ }^{1}$, Sabika Firasat ${ }^{1}$, Sarwat Jahan ${ }^{1}$, Mazhar Qayyum ${ }^{2}$
}

\begin{abstract}
1. Department of Zoology, Faculty of Biological Sciences, Quaid-i-Azam University Islamabad, 45320, Pakistan.

2. Department of Zoology and Biology, Faculty of Sciences, PMAS-Agriculture University, Rawalpindi-46300, Pakistan.
\end{abstract}

\begin{abstract}
Background: Fascioliasis has never been considered a public health concern in Pakistan, although the increasing numbers of human cases reported in south Asia need a re-consideration in the country. The current study aimed to find the seroprevalence of human fascioliasis, associated risk factors and its relationship with liver enzymes as biomarkers of pathogenicity.

Methods: The cross-sectional study was conducted in different districts of Punjab region from May 2014 to August 2016. A total of 546 respondents were screened by using enzyme-linked immunosorbent assay (ELISA) and serum biochemical tests.

Results: Higher seroprevalence was recorded in Muzaffargarh (6.2\%) and Bhara kahu (5.9\%), while low infection rate in Gujranwala $(1.1 \%)$ and Islamabad $(1.5 \%)$. The results of multiple logistic regression analysis showed rural inhabitants $(\mathrm{OR}=7.9$, 95\% CI: 2.5-24.8), females (OR=3.5, 95\%CI: 1.7-7.1), family size 3-7 (OR=1.7, 95\%CI: 1.0-2.9) and socioeconomic condition $(\mathrm{OR}=3.9,95 \% \mathrm{CI}: 1.5-10.4)$ were the significantly $(\mathrm{p}<0.005)$ associated risk factors with disease. The results of liver enzymes i.e. aspartate aminotransferase, alanine aminotransferase, alkaline phosphatase, gamma-glutamyl transferase and cholesterol levels were significantly $(\mathrm{p}=0.001)$ elevated and associated with fascioliasis pathogenicity.

Conclusion: The higher prevalence recorded may explain with Fasciola IgG antibodies for both active and past infections and cross reactivity of the assay with other helminthes.

Keywords: Human fascioliasis, immunodiagnosis, liver enzymes, Pakistan.

DOI: https://dx.doi.org/10.4314/ahs.v20i1.26

Cite as: Afshan K, Kabeer S, Firasat S, Jahan S, Qayyum M. Seroepidemiology of buman fascioliasis and its relationship with anti-Fasciola IgG and liver ensymes as biomarkers of pathogenicity. Afri Health Sci. 2020;20(1):208-18. https: / / dx.doi.org/10.4314/abs.v20i1.26
\end{abstract}

\section{Introduction}

Liver fluke infection known as fascioliasis is an emerging food-borne zoonosis, infecting a wide range of host species. Over 17 million people are affected globally, where humans become accidental hosts by ingestion of contaminated water, aquatic vegetation or occasionally through

\section{Corresponding author: \\ Kiran Afshan, \\ Department of Zoology, Faculty of Biological \\ Sciences, Quaid-i-Azam University Islamabad, 45320, Pakistan. \\ E-mail: kafshan@qau.edu.pk}

consumption of raw or undercooked liver products. ${ }^{1}$ The geographical distribution of fascioliasis is strongly linked to climate and environmental conditions such as presence of water bodies, pastures and wetlands. These conditions create a favourable environment for the development and transmission of free living fluke stages and for the growth and reproduction of the intermediate host Galba truncatula. ${ }^{2,3}$ Apart from climate and environmental factors, anthropogenic modifications of the environment ${ }^{4}$, travelling ${ }^{5}$ and import/export of livestock ${ }^{1}$ are also associated with occurrence of the infection. ${ }^{6,7}$

The symptoms associated with human fascioliasis appears to be pronouncedly complicated including diagnosis difficulties ${ }^{8}$ and remained underestimated in countries, especially where animal fascioliasis is prevalent. This is 
because parasitological diagnosis of human fascioliasis is often unreliable since the parasite eggs are not found in the stool during the early phase of infection. Even when the flukes maturated, diagnosis may still be difficult due to intermittent shedding of parasite eggs. ${ }^{9}$ Moreover, symptoms in the acute phase of disease are not pathognomonic and may mimic a wide spectrum of hepatic and intestinal pathologies such that the diagnosis may be delayed. ${ }^{10}$ Because of these reasons, serological diagnosis is preferred, particularly since antibodies to Fasciola can be detected as early as 2 weeks after infection, which can facilitate early treatment before irreparable damage to the liver occurs.

Human fascioliasis has been recognized as a major public health concern by World Health Organization, ${ }^{11}$ however it has never been given much importance in southern Asia. In south Asian countries, human cases are mainly reported in Iran, ${ }^{12,13}$ dispersed number of cases in India ${ }^{14}$ and numerous cases in Vietnam. ${ }^{15,16}$ In Pakistan, however very few human fascioliasis cases has been reported from the Punjab province. ${ }^{17,18}$ Hence, higher prevalences may be expected in this Punjab area when applying highly sensitive and specific serological tests. ${ }^{8}$ These very few reports indicating prevalence of human infection and risk of infection in other areas of Punjab indicated with environmental study ${ }^{4}$ has encouraged exploring more areas of Punjab province with most sensitive and specific diagnostic assays.
Preliminary work on human fascioliasis in Pakistan was based on coprology ${ }^{17}$ and indirect haemagglutination (IHA) test ${ }^{18}$, were less sensitive techniques. Recently 1200 subjects were screened based on coprological examination in Punjab and provided an overall prevalence of $1.18 \%{ }^{19}$ which motivated application of most sensitive and specific diagnostic tests in this area to find baseline data of disease. The aim of the present study is to find the serological evidence of human fascioliasis and its relationship with liver enzymes as biomarkers of pathogenicity which could be predictive of disease.

\section{Materials and methods \\ Study Area}

The study area comprises north, central and south of the Punjab province, namely: Bharakahu, Golra Mor, Islamabad, Rawalpindi, Faisalabad, Gujrawala and Muzaffargarh [Fig. 1]. The north of Punjab comprises of pasture land and livestock rearing is the main source of income for the farmers. The central Punjab comprises of irrigated land having well established water channel system of Indus river basin. In irrigated areas of central Punjab every farmer allots a piece of land for planting fodder crops. South of Punjab is comprised of alluvial plains and is ideal for agriculture, with arid climate. During the monsoon season, the land close to the Chenab is usually flooded.
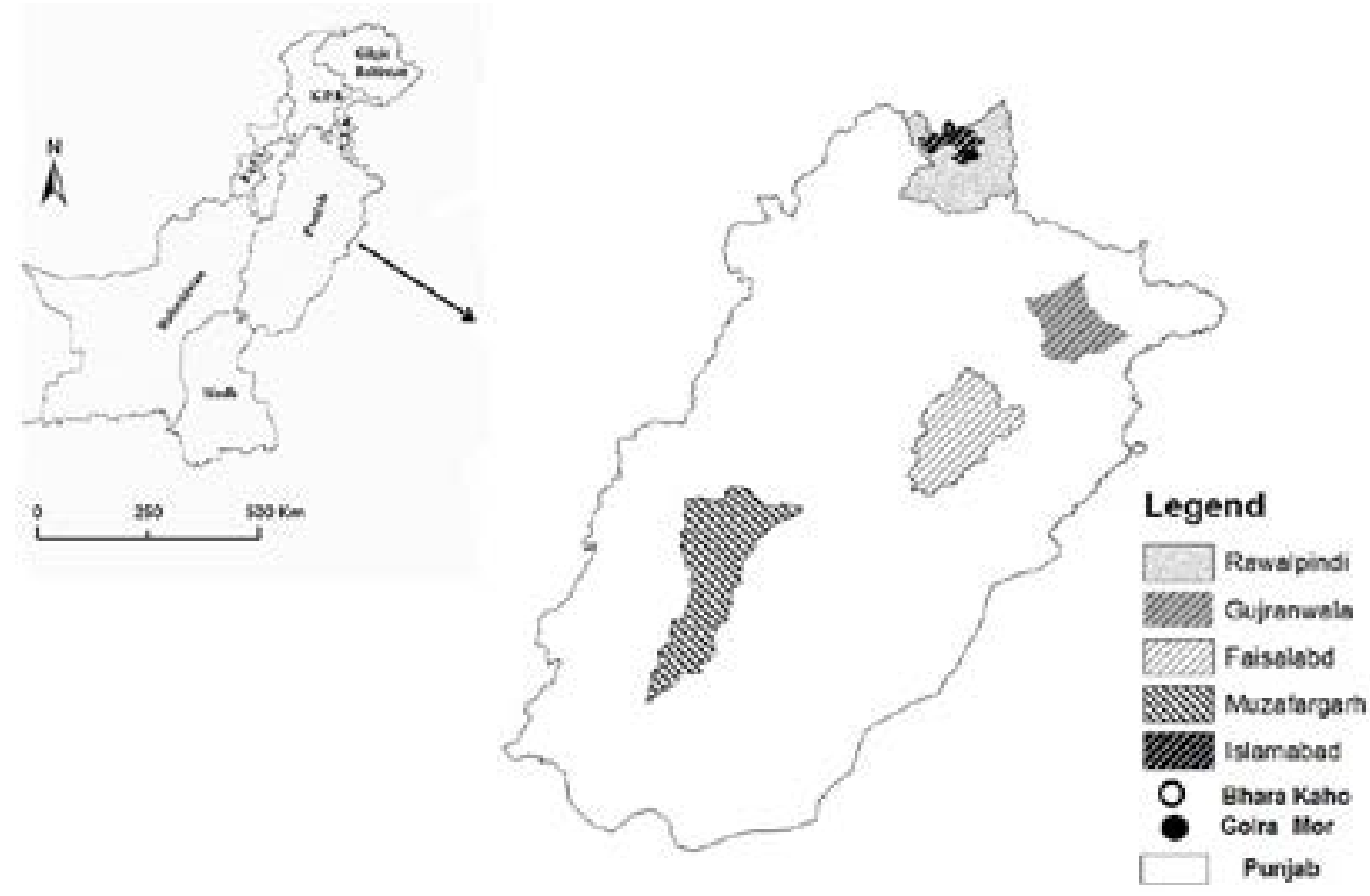

Figure 1: Map of Pakistan to show Punjab indicating sampling sites. 


\section{Blood sample collection}

The sample size of 546 was selected randomly from risk populations who drink untreated/recreational water and had history of eating uncooked/raw vegetables. The sampling was conducted from May 2014-August 2016. A questionnaire was used to obtain demographic information as well as information on participant education, occupation, hygiene, water supply facilities, and eating of freshwater vegetables. The subjects having history of hepatitis were excluded from the study. Blood was obtained from all consenting subjects, and sera were separated and stored at $-20 \circ \mathrm{C}$ until assayed. The sera positive for other than Fasciola infection $(\mathrm{n}=49)$ mainly: ascariasis, trichuriasis, malaria, amebasis; leishmaniasis and toxoplasmosis were taken from clinically confirmed cases from hospitals to check the cross reactivity of the test. The sera for negative control $(n=33)$ were taken from parasitologically negative cases.

\section{Enzyme-linked Immunosorbent Assay}

Fasciola IgG Enzyme Immunoassay Kits (DRG diagnostics $\mathrm{GmbH}$, Germany) were used for the detection of $\mathrm{IgG}$ antibodies against fascioliasis. All steps and results were interpreted according to the manufacturer's instructions. Briefly, antigen coated microtiter plates were incubated with $100 \mu \mathrm{l}$ of a serum samples at $37^{\circ} \mathrm{C}$ for $1 \mathrm{hr}$. Plates were washed 5 times with washing buffer. Enzyme conjugate $(100 \mu \mathrm{l} /$ well) was added and incubated at room temperature for $30 \mathrm{~min}$. After final washing step $100 \mu \mathrm{l}$ of substrate solution was added to wells and reaction was stopped with adding $100 \mu \mathrm{l}$ of stopper solution. Optical density (OD) was measured at $450 \mathrm{~nm}$ with ELISA reader (Bio-Red). The results in DRG Units (DU) were calculated according to the following formula:

$$
D U=\frac{\text { Sample mean absorbance value } \times 10}{\text { Cutoff control }}
$$

The results were positive if $\mathrm{DU}>11$.

\section{Serum Biochemical Study}

Fasciola positive patients $(\mathrm{n}=80)$ with $\mathrm{DU} \geq 13$ and negative patients $(n=20)$ with $D U \leq 1$ were selected for biochemical assays. The activity of serum aspartate aminotransferase (AST), alanine aminotransferase (ALT), alkaline phosphatase (ALP), gamma-glutamyl transferase (GGT), total protein, globulin, albumin, glucose and cholesterol were measured by using biochemistry analyzer. Assays were performed according to manufactured instructions (Spectrum \& Futura system group).

\section{Statistical analysis}

All data derived from questionnaires and after immunological examinations were entered and analysed by using Statistical Package for the Social Sciences (SPSS) Ver. 20. The frequencies and percentages for categorical variables were calculated by univariate descriptive analysis and independent variable were initially assessed by Chi-Square test. Subsequently, stepwise logistic regression was used. The odds ratios (OR) with 95\% confidence intervals (CI) was computed by the multivariate logistic regression analysis to approximate the relative risk of fascioliasis associated with exposure. A significant level of $p<0.05$ was adopted for all tests. Independent sample t-test was used for biochemical analysis.

\section{Results}

\section{Overall Seropositivity of Fasciola IgG}

The sensitivity (92.31\%; 95\% CI: $63.97 \%$ to $99.81 \%$ ) and specificity (93.94\%; 95\% CI: $79.77 \%$ to $99.26 \%$ ) of the assay was determined to test the diagnostic performance of Fasciola IgG human ELISA test (Table 1).

Table 1: Diagnostic performance of the Fasciola IgG ELISA test.

\begin{tabular}{cccc}
\hline ELISA & $\begin{array}{c}\text { Parasitic } \\
\text { infections* other } \\
\text { than Fasciola } \\
\mathbf{n}(\mathbf{\%})\end{array}$ & $\begin{array}{c}\text { Control } \\
\text { Negative } \\
\mathbf{n ~ ( \% )}\end{array}$ & $\begin{array}{c}\text { Fasciola positive } \\
\mathbf{n}(\mathbf{\%}) * *\end{array}$ \\
\hline+ & $5(10.2)$ & $2(6.06)$ & $12(92.30)$ \\
- & $44(89.79)$ & $31(93.93)$ & $1(7.69)$ \\
Total Number & 49 & 33 & 13 \\
* Other parasitic infections i.e. Ascariasis, Trichuriasis, Malaria, Amebiasis; \\
*eishmaniasis and Toxoplasmosis \\
**arentheses represent percentages.
\end{tabular}




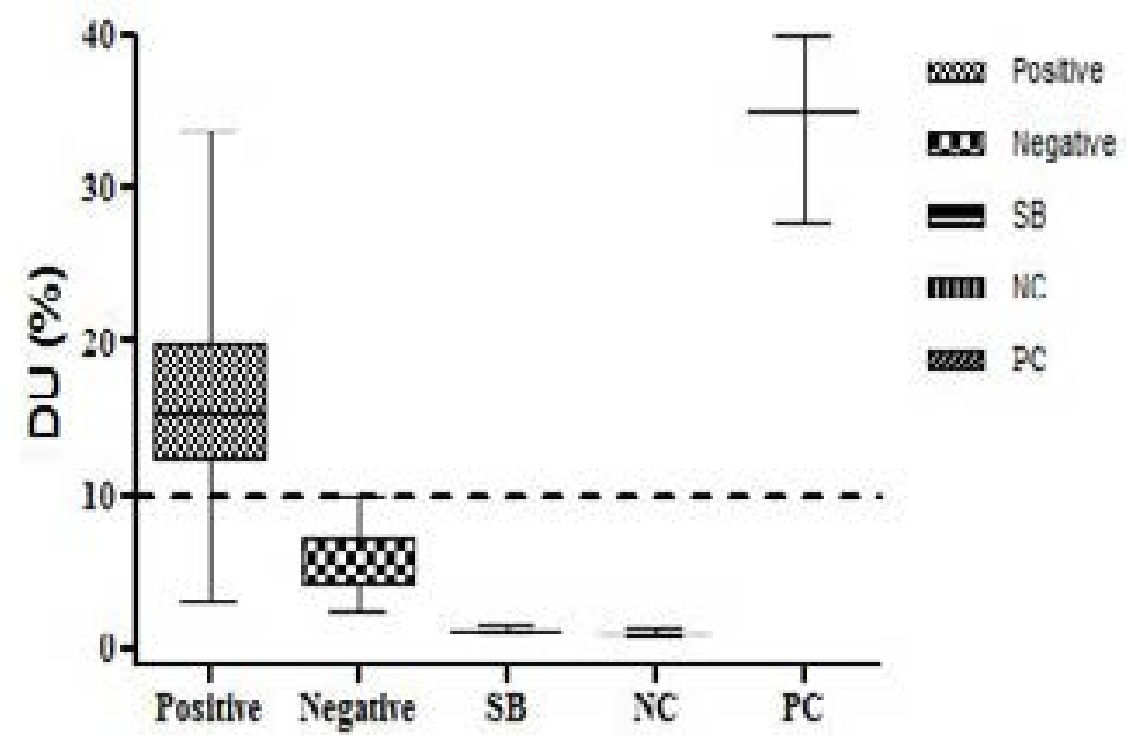

Figure 2: Mean DRG Units (DU) obtained with the DRG Fasciola IgG ELISA test in population with fascioliasis positive, negative and control sera (Substrate blank (SB); Negative control (NC), Positive control (PC). A serum is considered positive when its absorbance value is above $10 \%$ of cut-off. The results were negative if $\mathrm{DU}<9$, positive if $\mathrm{DU}>11$ and in Grey zone if DU $>9$ and $\mathrm{DU}<11$.

The antibody level was above the cut-off value in all infected individuals ( $\mathrm{DU} \geq 11)$. In a total of 546 individuals $23.8 \%$ were found seropositive, 380(69.6) were negative with $\mathrm{DU}<11$. Table 2 represents the prevalence percentages against fascioliasis, which included 36 (6.6\%) female and $94(17.2 \%)$ males. The infection was observed higher in Muzaffargarh 34 (6.2\%) and $32(5.9 \%)$ in Bhara kahu, while low seroprevalence was recorded in Gujranwala 6 $(1.1 \%)$ and Islamabad $8(1.5 \%)$. Prevalence was significantly $(\mathrm{p}<0.05)$ higher in rural communities $120(22.0 \%)$, in summer season $78(14.3 \%)$ and among male groups
94(17.2\%). Results obtained showed overall infection rates being highest in the 20-29-year-age group 32(5.9\%), followed by the 10-19-year-age group $28(5.1 \%)$ and 3039 year-age group $28(5.1 \%)$, while very low infection was found in subjects above 50 years. These prevalence differences between age groups appeared to be statistically significant $(\mathrm{p}<0.05)$. Result indicated significantly high prevalences with family size 8-12 60(11\%), those having causal hygiene $76(13.9 \%)$ and with poor socio-economic status $96(17.6 \%)$. Infection was found higher among those drinking untreated water $122(22.3 \%)$ and having 11-20 ruminants $60(11 \%)$. 
Table 2: Epidemiological survey of human fascioliasis according to demographic, socioeconomic and household-level risk factors in Punjab, Pakistan: results of univariate and multivariate logistic regression analysis.

\begin{tabular}{|c|c|c|c|c|c|c|c|c|c|}
\hline \multirow{3}{*}{ Characteristics } & \multicolumn{4}{|c|}{ Univariate Analysis } & \multicolumn{5}{|c|}{ Multivariate Logistic Regression } \\
\hline & \multirow{3}{*}{$\begin{array}{c}\text { Positive } \\
\text { n(\%) }\end{array}$} & \multirow{2}{*}{$\begin{array}{c}\text { Negative } \\
\text { n(\%) }\end{array}$} & \multirow{2}{*}{$\begin{array}{c}\text { Gray } \\
\text { zone } \\
\text { n(\%) } \\
\end{array}$} & \multirow[t]{2}{*}{ Chi-square } & \multirow[t]{2}{*}{$\boldsymbol{\beta}$} & \multirow[t]{2}{*}{$\begin{array}{c}\text { p- } \\
\text { value }\end{array}$} & \multirow[t]{2}{*}{ OR } & \multicolumn{2}{|c|}{ 95\% C.I. for OR } \\
\hline & & & & & & & & Lower & Upper \\
\hline City & & & & & & $0.00^{* *}$ & & & \\
\hline Barakahu & $32(5.9)$ & $32(5.9)$ & $10(1.8)$ & $94.31 * *$ & -0.08 & $0.94^{\mathrm{NS}}$ & 0.93 & 0.13 & 6.49 \\
\hline Faisalabad & $20(3.7)$ & $34(6.2)$ & $4(0.7)$ & & -0.57 & $0.58^{\mathrm{NS}}$ & 0.57 & 0.08 & 4.23 \\
\hline Golramor & $14(2.6)$ & $76(13.9)$ & $4(0.7)$ & & -1.29 & $0.05 *$ & 0.27 & 0.08 & 0.99 \\
\hline Gujranwala & $6(1.1)$ & $80(14.7)$ & $2(0.4)$ & & -2.76 & $0.00 * *$ & 0.06 & 0.01 & 0.29 \\
\hline Islamabad & $8(1.5)$ & $94(17.2)$ & $6(1.1)$ & & -3.14 & $0.01 * *$ & 0.04 & 0.00 & 0.39 \\
\hline Rawalpindi & $16(2.9)$ & $26(4.8)$ & $6(1.1)$ & & -0.60 & $0.55^{\mathrm{NS}}$ & 0.55 & 0.08 & 3.99 \\
\hline Muzaffargarh & $34(6.2)$ & $38(7.0)$ & $4(0.7)$ & & Ref & & & & \\
\hline \multicolumn{10}{|l|}{ Locality } \\
\hline Rural & $120(22.0)$ & $288(52.7)$ & $32(5.9)$ & $18.59 * *$ & 1.68 & $0.03 *$ & 5.39 & 1.18 & 24.57 \\
\hline Urban & $10(1.8)$ & $92(16.8)$ & $4(0.7)$ & & Ref & & & & \\
\hline Season & & & & & & & & & \\
\hline Summer & $78(14.3)$ & $168(30.8)$ & $26(4.8)$ & $17.40^{* *}$ & 1.11 & $0.20^{\mathrm{NS}}$ & 3.03 & 0.57 & 16.16 \\
\hline Winter & $52(9.5)$ & $212(38.8)$ & $10(1.8)$ & & Ref & & & & \\
\hline Gender & & & & & & & & & \\
\hline Female & $36(6.6)$ & $20(3.7)$ & $4(0.7)$ & $49.82 * *$ & 1.19 & $0.00 * *$ & 3.29 & 1.62 & 6.69 \\
\hline Male & $94(17.2)$ & $360(65.9)$ & $32(5.9)$ & & Ref & & & & \\
\hline Age & & & & & & $0.51^{\mathrm{NS}}$ & & & \\
\hline 10 to 19 & $28(5.1)$ & $38(7.0)$ & $4(0.7)$ & $52.24 * *$ & 0.28 & $0.71^{\mathrm{NS}}$ & 1.32 & 0.30 & 5.79 \\
\hline 20 to 29 & $32(5.9)$ & $96(17.6)$ & $4(0.7)$ & & 0.22 & $0.75^{\mathrm{NS}}$ & 1.25 & 0.31 & 5.08 \\
\hline 30 to 39 & $28(5.1)$ & $118(21.6)$ & $10(1.8)$ & & -0.14 & $0.84^{\mathrm{NS}}$ & 0.87 & 0.23 & 3.33 \\
\hline 40 to 49 & $22(4.0)$ & $94(17.2)$ & $4(0.7)$ & & 0.13 & $0.85^{\mathrm{NS}}$ & 1.14 & 0.30 & 4.36 \\
\hline 50 to 59 & $16(2.9)$ & $26(4.8)$ & $8(1.5)$ & & 0.71 & $0.31^{\mathrm{NS}}$ & 2.04 & 0.52 & 8.05 \\
\hline 60 to 69 & $4(0.7)$ & $8(1.5)$ & $6(1.1)$ & & Ref & & & & \\
\hline $\begin{array}{l}\text { History eating } \\
\text { vegetables }\end{array}$ & $130(23.8)$ & $380(69.6)$ & $36(6.6)$ & $\mathrm{nc}$ & $\mathrm{nc}$ & & & & \\
\hline Education & & & & & & $0.78^{\mathrm{NS}}$ & & & \\
\hline Illeterate & $98(17.9)$ & $292(53.5)$ & $28(5.1)$ & $2.45^{\mathrm{NS}}$ & 0.69 & $0.50^{\mathrm{NS}}$ & 1.99 & 0.27 & 14.71 \\
\hline Primary & $24(4.4)$ & $54(9.9)$ & $6(1.1)$ & & 0.68 & $0.49^{\mathrm{NS}}$ & 1.96 & 0.29 & 13.21 \\
\hline Secondary + & $8(1.5)$ & $34(6.2)$ & $2(0.4)$ & & Ref & & & & \\
\hline Family size & & & & & & $0.07^{\mathrm{NS}}$ & & & \\
\hline 13 to 17 & $14(2.6)$ & $12(2.2)$ & $2(0.4)$ & $18.62 * *$ & 1.05 & $0.05 *$ & 2.85 & 1.01 & 8.02 \\
\hline 18 to 22 & $6(1.1)$ & $10(1.8)$ & $0(0.0)$ & & 0.40 & $0.54^{\mathrm{NS}}$ & 1.49 & 0.41 & 5.49 \\
\hline & & & & & - & $1.00^{\mathrm{NS}}$ & 0.00 & 0.00 & \\
\hline 23 to 27 & $0(0.0)$ & $6(1.1)$ & $0(0.0)$ & & 18.48 & & & & \\
\hline 3 to 7 & $50(9.2)$ & $136(24.9)$ & $12(2.2)$ & & 0.76 & $0.01 * *$ & 2.14 & 1.22 & 3.76 \\
\hline 8 to 12 & $60(11.0)$ & $216(39.6)$ & $22(4.0)$ & & Ref & & & & \\
\hline Personal hygiene & & & & & & $0.38^{\mathrm{NS}}$ & & & \\
\hline Casual (normal) & $76(13.9)$ & $200(36.6)$ & $16(2.9)$ & $3.39^{\mathrm{NS}}$ & -0.39 & $0.22^{\mathrm{NS}}$ & 0.68 & 0.36 & 1.26 \\
\hline Good & $22(4.0)$ & $66(12.1)$ & $6(1.1)$ & & 0.02 & $0.95^{\mathrm{NS}}$ & 1.02 & 0.52 & 2.00 \\
\hline Poor & $32(5.9)$ & $114(20.9)$ & $14(2.6)$ & & Ref & & & & \\
\hline Feeding habit & & & & & & & & & \\
\hline Mix(vegetables + meat) & $130(23.8)$ & $380(69.6)$ & $36(6.6)$ & nc & nc & & & & \\
\hline $\begin{array}{l}\text { Source of drinking } \\
\text { water }\end{array}$ & & & & & & & & & \\
\hline Treated & $8(1.5)$ & $104(19.0)$ & $2(0.4)$ & $31.87 * *$ & -1.42 & $0.00 * *$ & 0.24 & 0.11 & 0.54 \\
\hline Untreated & $122(22.3)$ & $276(50.5)$ & $34(6.2)$ & & Ref & & & & \\
\hline Cooking methods & & & & & & & & & \\
\hline Properly & $84(15.4)$ & $328(60.1)$ & $28(5.1)$ & $29.35 * *$ & 0.18 & $0.69^{\mathrm{NS}}$ & 1.20 & 0.49 & 2.93 \\
\hline Raw cook & $46(8.4)$ & $52(9.5)$ & $8(1.5)$ & & Ref & & & & \\
\hline Medication & & & & & & & & & \\
\hline Treated & $76(13.9)$ & $334(61.2)$ & $30(5.5)$ & $53.82 * *$ & -1.73 & $0.00 * *$ & 0.18 & 0.07 & 0.44 \\
\hline Untreated & $54(9.9)$ & $46(8.4)$ & $6(1.1)$ & & Ref & & & & \\
\hline Contact with water & & & & & & & & & \\
\hline bodies & $130(23.8)$ & $380(69.6)$ & $36(6.6)$ & $\mathrm{nc}$ & $\mathrm{nc}$ & & & & \\
\hline 11 to 20 & $60(11.0)$ & $126(23.1)$ & $12(2.2)$ & $36.49 * *$ & $\mathrm{nc}$ & & & & \\
\hline 1 to 10 & $50(9.2)$ & $102(18.7)$ & $8(1.5)$ & & & & & & \\
\hline 21 to 30 & $8(1.5)$ & $82(15.0)$ & $12(2.2)$ & & & & & & \\
\hline 31 to 40 & $12(2.2)$ & $50(9.2)$ & $4(0.7)$ & & & & & & \\
\hline 41 to 50 & $0(0.0)$ & $20(3.7)$ & $0(0.0)$ & & & & & & \\
\hline Socioeconomic condition & & & & & & $0.03 *$ & & & \\
\hline Good & $4(0.7)$ & $26(4.8)$ & $4(0.7)$ & $33.23 * *$ & 0.63 & $0.41^{\mathrm{NS}}$ & 1.89 & 0.41 & 8.60 \\
\hline Normal & $30(5.5)$ & $170(31.1)$ & $6(1.1)$ & & 1.35 & $0.01 * *$ & 3.86 & 1.38 & 10.86 \\
\hline Poor & $96(17.6)$ & $184(33.7)$ & $26(4.8)$ & & Ref & & & & \\
\hline
\end{tabular}

$\beta$ Coefficient of regression; OR odd ratio; C.I. Confidence Interval; ${ }^{N S}$ not Significant; *Significant $p<0.05 ; * *$ highly significant $p<0.01$; ne values not computed

Risk factors associated with fascioliasis seropositivity

The univariate analysis indicated that almost all sociodemographic variables such as cities, locality, season, gender, age, family size, source of drinking water, cooking methods, medication, number of ruminants and socioeconomic condition showed significant $(\mathrm{p}<0.0001 /$ $\mathrm{p}<0.05)$ association with fascioliasis seropositivity. However, education $\left(\chi^{2}=2.451, \mathrm{p}=0.643\right)$ and personal hygiene $\left(\chi^{2}=3.389, \mathrm{p}=0.495\right)$ did not show significant asso- 
ciation ( $p>0.05$ ) with fascioliasis seropositivity (Table 2). In multivariate analysis, stepwise logistic regression technique was used and the relative effect of the independent variable on the outcome variable was determined. In doing so, to avoid an excessive number of variables and unstable estimates in the subsequent model, demographic variables and other associated risk factors were kept separately in the subsequent analyses. In multivariate analysis of demographic factors for City, Golra Mor ( $\mathrm{OR}=0.27,95 \%$ CI: 0.08-0.99), Gujranwala ( $\mathrm{OR}=0.06$, 95\% CI: $0.01-0.29$ ), and Islamabad (OR $=0.04,95 \%$ CI: $0.00-0.39)$ showed significantly $(\mathrm{p}<0.05)$ decreasing trend in human fascioliasis as compared to Muzaffargarh. Inhabitants of rural communities (OR=5.39, 95\% CI: 1.1824.57), having female gender ( $\mathrm{OR}=3.29,95 \% \mathrm{CI}$ : 1.62 6.69) and normal socio-economic condition ( $\mathrm{OR}=3.86$, 95\% CI: $1.38-10.86)$ showed significantly $(\mathrm{p}<0.05)$ increasing human fascioliasis risk than urban communities, males and poor socio-economic condition respectively. Family size with 3-7 (OR=2.14, 95\% CI: 1.22-3.76) and 13-17 (OR=2.85, 95\% CI: 1.01-8.02) showed significantly $(\mathrm{p}<0.05)$ increasing fascioliasis seropositivity than those having 8-12 family size. However, season, age groups and education did not showed significant $(p>0.05)$ associa- tion with fascioliasis seropositivity (Table 2).

In subsequent multivariate analysis for associated risk factor namely: eating and drinking habits, cooking methods, personal hygiene and medication, only two of them showed significantly $(\mathrm{p}<0.0005)$ decreasing human fascioliasis risk in population having treated source of drinking water (OR=0.29, 95\% CI: 0.14-0.64) and used medication (OR=0.15, 95\% CI: 0.06-0.34) (Table 2).

Only significantly associated risk factors aforementioned were analysed in final multivariate model. Among cities Bhara kahu (OR=12.76, 95\% CI: 3.79-43.02), Faisalabad (OR=10.71, 95\% CI: 2.88-39.77) and Rawalpindi (OR=11.46, 95\% CI: 2.93-44.81) showed significantly $(\mathrm{p}<0.01)$ increasing risk of human fascioliasis than Muzaffargarh. Rural inhabitants (OR=7.94, 95\% CI: 2.5324.87), females (OR=3.55, 95\% CI: 1.76-7.13), having family size $3-7$ (OR=1.71, 95\% CI: 1.00-2.95) and with normal socioeconomic condition (OR=3.97, 95\% CI: $1.51-10.41)$ showed significantly $(\mathrm{p}<0.05)$ increasing risk human fascioliasis seropositivity. However, people regularly treated with medication $(\mathrm{OR}=0.13,95 \%$ CI: 0.05 0.35) showed decreasing risk of human fascioliasis (Table 3). 
Table 3: Final multivariate logistic regression model of risk factors and their association with human fascioliasis in Punjab, Pakistan.

\begin{tabular}{|c|c|c|c|c|c|c|}
\hline \multirow[t]{2}{*}{ Characteristics } & \multirow[t]{2}{*}{$\boldsymbol{\beta}$} & \multirow[t]{2}{*}{ S.E. } & \multirow[t]{2}{*}{ p-value } & \multirow[t]{2}{*}{ OR } & \multicolumn{2}{|c|}{$\begin{array}{c}\text { 95\% C.I. for } \\
\text { OR }\end{array}$} \\
\hline & & & & & Lower & Upper \\
\hline Constant & -3.40 & 0.73 & 0.00 & 0.03 & & \\
\hline \multicolumn{7}{|l|}{ City } \\
\hline Bhara kahu & 2.55 & 0.62 & $0.00 * *$ & 12.76 & 3.79 & 43.02 \\
\hline Faisalabad & 2.37 & 0.67 & $0.00 * *$ & 10.71 & 2.88 & 39.77 \\
\hline Rawalpindi & 2.44 & 0.70 & $0.00 * *$ & 11.46 & 2.93 & 44.81 \\
\hline Muzaffargarh & & & & Ref & & \\
\hline \multicolumn{7}{|l|}{ Locality } \\
\hline Rural & 2.07 & 0.58 & $0.00 * *$ & 7.94 & 2.53 & 24.87 \\
\hline Urban & & & & Ref & & \\
\hline \multicolumn{7}{|l|}{ Gender } \\
\hline Female & 1.27 & 0.36 & $0.00 * *$ & 3.55 & 1.76 & 7.13 \\
\hline Male & & & & Ref & & \\
\hline \multicolumn{7}{|l|}{ Family Size } \\
\hline $3-7$ & 0.54 & 0.28 & $0.05^{*}$ & 1.71 & 1.00 & 2.95 \\
\hline $8-12$ & & & & Ref & & \\
\hline \multicolumn{7}{|l|}{ Medication } \\
\hline Treated & -2.06 & 0.51 & $0.00 * *$ & 0.13 & 0.05 & 0.35 \\
\hline Untreated & & & & Ref & & \\
\hline \multicolumn{7}{|l|}{$\begin{array}{l}\text { Socioeconomic } \\
\text { Condition }\end{array}$} \\
\hline Normal & 1.38 & 0.49 & $0.01 * *$ & 3.97 & 1.51 & 10.41 \\
\hline Poor & & & & Ref & & \\
\hline
\end{tabular}

\section{Biochemical assays}

Biochemical changes in Fasciola infected patients and control group are summarized in Table 4. The result showed that liver enzymes serum alanine aminotransferase (ALT), aspartate aminotransferase (AST), alkaline phosphate(ALP) and gamma glutamyltransferase (GGT) level were elevated significantly $(\mathrm{p}<0.001)$ in Fasciola patients as compared to control group. Serum total pro- tein, albumin and globulin results indicated no significant $(\mathrm{p}=0.812)$ change between infected and control groups. This study indicated that cholesterol level was significantly $(\mathrm{p}<0.0001)$ elevated in Fasciola positive group as compared to controls. The result showed very small increase in serum glucose level in infected group, while no significant ( $p>0.05)$ difference was found when comparing fascioliasis positive group with controls. 
Table 4: Biochemical changes between Fasciola IgG positive cases and controls.

\begin{tabular}{ccccc}
\hline Variables & $\begin{array}{c}\text { Infected group } \\
(\mathbf{n}=\mathbf{8 0}) \\
\text { Mean } \pm \text { SD }\end{array}$ & $\begin{array}{c}\text { Control group } \\
(\mathbf{n}=\mathbf{2 0}) \\
\text { Mean } \pm \text { SD }\end{array}$ & t-value & p-value \\
& & & & \\
\hline Liver Enzymes & $78.80 \pm 43.14$ & $18.80 \pm 17.99$ & 6.75 & $0.000^{* *}$ \\
ALT (U/I) & $109.40 \pm 52.49$ & $19.70 \pm 15.54$ & 9.29 & $0.000^{* *}$ \\
AST (U/I) & $263.7 \pm 116.56$ & $57.53 \pm 29.91$ & 9.95 & $0.000^{* *}$ \\
ALP (U/L) & $125.73 \pm 117.77$ & $21.70 \pm 25.41$ & 5.12 & $0.000^{* *}$ \\
GGT (U/L) & & & & \\
Serum Proteins & $6.60 \pm 1.12$ & $6.50 \pm 1.17$ & 0.24 & $0.812^{\mathrm{NS}}$ \\
Total protein (g/dL) & $4.13 \pm .79$ & $4.10 \pm .99$ & 0.07 & $0.942^{\mathrm{NS}}$ \\
Albumin (g/dL) & $2.38 \pm 1.13$ & $2.26 \pm 1.36$ & 0.28 & $0.804^{\mathrm{NS}}$ \\
Globulin (g/dL) & $154.29 \pm 31.07$ & $84.76 \pm 17.41$ & 9.42 & $0.000^{* *}$ \\
Cholesterol (mg/d) & $55.91 \pm 38.61$ & $54.34 \pm 63.84$ & 0.07 & $0.940^{\mathrm{NS}}$ \\
Glucose (mg/dl) & & & & \\
\hline
\end{tabular}

** $\mathrm{p}<0.01,{ }^{\mathrm{NS}} \mathrm{p}>0.05$

\section{Discussion}

The present study found overall prevalence of $23.8 \%$, which showed much higher infection rate than reported previously. ${ }^{17,19}$ Immunodiagnostic tests against fascioliasis are valuable for compiling epidemiological data and used as additional tools in clinical diagnosis to detect specific antibodies with great precision. ${ }^{20}$ High frequency of human fascioliasis in studied areas can be explained by the fact that people in this region consume large amounts of raw uncooked vegetables and drink contaminated water. ${ }^{21}$ High prevalence in the current study may be one limitation of serological tests to differentiate between active and past infection, it may be due to cross reactivity of sero test with other parasites. In Pakistan,the first report on human fascioliasis appeared in $2005^{17}$ and high human fascioliasis transmission risk were determined in Punjab. ${ }^{4}$ Previously low infection rates recorded were due to application of less sensitive microscopic techniques. ${ }^{17,19}$ The possible reason of low infection rate with microscopic techniques was explained by Mas-coma et al. ${ }^{8}$ That inEurope, Vietnam and Mexico low human infection reports were due to irregular shedding of eggs in faeces, occurrence of very few flukes in individuals with chronic infections and inability of the parasite to establish in the body of the human host to get maturity.

The current result showed higher seroprevalence in northern and southern Punjab. The increasing fascioliasis trend in the north can be explained by the fact that heavy rain fall in these areas provides breeding grounds for its lymnaeid intermediated host(s). However, the southern areas of Punjab have low precipitation and agricultural activities based on irrigation system with extensive network of water channels, which provides suitable persistent habitat for lymnaeid snails.

The seroprevalence was found to be high $5.9 \%$ and $5.1 \%$ in 20-29 and 10-19 years age groups respectively. However, seroprevalence decreased in old age groups above 50 years. The higher rate of infection in people having age groups from 10-40 years may reflect the increased possibility of encountering the parasite with aging. ${ }^{22}$ In the present study, fascioliasis was more prevalent in males than in females. However, multivariate analysis showed that females were at higher risk of acquiring fasciolid infections as compared with males. This may be attributed to females eating green aquatic plants more frequently than males. ${ }^{22}$

Several lifestyle factors have been found to increase the risk of fasciolid infection in human populations. In the current findings most fasciolid infections in rural populations of Pakistan are probably acquired through consumption of raw vegetables and drinking untreated water contaminated with metacercariae. Similar findings were reported in other studies where high fasciolid infection was recorded in rural communities with poor sanitation practices. $^{19,23}$

The high infection rate was recorded in summer as compared to winter season. The results were consistent with findings that recorded significantly higher human fascioliasis in summer and autumn as compared to winter and spring. ${ }^{19}$ Other studies recorded fascioliasis transmission 
risk shows biseasonality in Punjab, with a transmission peak in July-August due to rainfall and a February-March peak linked to man made irrigation systems. ${ }^{4}$

Low socioeconomic status and residence in rural areas are additional factors contributing to fascioliasis infection in Pakistani communities. The results were consistent with study reported in Iran that fascioliasis seropositivity was a higher in low literate people. ${ }^{21}$ However in the present study, uneducated people did not show significantly higher risk of human fascioliasis. The current results recorded that the prevalence of fascioliasis decreases with increasing number of domestic ruminants. The association between domestic ruminants and risk of human infection with fascioliasis is difficult to assess, because transmission depends on drinking contaminated water with metacercariae and eating raw uncooked green vegetables, rather than direct exposure to domestic livestock.

The present study revealed elevated level of aspartate aminotransferase and alkaline phosphate in Fasciola infected patients. Many biologists reported that ALT and AST activities increased among patients who had acute Fasciola infection. ${ }^{24,25}$ The higher value of ALT and AST is due to the stage of extensive destruction of the hepatic parenchyma which linked with some degree of hepatic necrosis that occurs during migration of immature worms. ${ }^{26} \mathrm{~Pa}$ renchymal damage in human fascioliasis occurs due to the activity of AST. ${ }^{27}$ In the present study the alkaline phosphate in Fasciola patients was elevated significantly. Previous studies showed that elevation of serum ALP causes signs and symptoms of abdominal pain, pain in the upper right quadrant, biliary colic, and jaundice that is linked with bile duct obstruction by the action of adult parasite and cholestasis occurs with inflammation. ${ }^{28,29}$ The result revealed elevated gamma glutamyl transferase (GGT) level, which results from hyperplasia, inflammation, bile duct damage, fibrosis and hepatic damage by larval immigration. ${ }^{26}$ It was previously observed that cholestasis, together with biliary obstruction is caused by the high activity of microsomal enzyme GGT. ${ }^{30}$ The current elevated levels of liver enzymes detected acute or chronic phase of fasciolosis. Furthermore, the present elevated serum cholesterol value is due to the extensive synthesis of bile acids which formed from cholesterol in the liver and transformed to bile acid in hepatocyte and following the regulation of bile acid metabolism. ${ }^{31}$ In the present study serum protein, albumin, globulin and glucose level remained normal in Fasciola infected patients. These findings were in agreement with a previous study ${ }^{32}$ and this may be due to high concentration of proteins that help in preparation of prolonged defense.

\section{Conclusion}

The results showed higher prevalence of human fascioliasis in study areas, and most associated risk factors were poor socioeconomic status, drinking untreated water and eating uncooked/raw vegetables. The liver enzymes including: AST, ALT, ALP, GGT and serum cholesterol levels were much elevated in infected patients and could be used as effective biomarkers of pathogenicity in acute and chronic phase of disease. The current result indicates that human infection situation is a public health concern for the Pakistani population. Furthermore, serological studies along with liver enzymes tests are recommended to generate accurate baseline data on fascioliasis which was previously underestimated in the country.

\section{Declaration of conflicting interests}

The authors declared no conflicts of interest with respect to the research, authorship, and/or publication of this article.

\section{Funding}

The research work presented in this article is part of studies carried out in research project (No. IPFP/HRD/ HEC/2014/1671) funded by the Higher Education Commission, Pakistan.

\section{Research ethics committee}

The study was conducted by following the ethical guideline approved by the Ethical Committee of Quaid-i-Azam University Islamabad, Pakistan. All participants gave written consent to provide blood samples and were informed on the nature of the study, benefits and risks.

\section{Author's contribution}

KA designed the study. SK, KA performed the experiment. KA, SF carried out search, data analysis and manuscript preparation. SF, SJ and MQ advised on methods and interpretation of findings. SJ and MQ reviewed the manuscript. All authors have participated in the study and concur with the submission and subsequent revisions submitted by the corresponding author. 


\section{References}

1. Mas-Coma S, Valero MA, Bargues MD. Fasciola, lymnaeids and human fascioliasis with a global overview on disease transmission, epidemiology, evolutionary genetics, molecular epidemiology and control. Adv Parasitol 2009; 69:41-146.

2. Charlier J, Bennema SC, Caron Y, Counotte M, Ducheyne E, Hendrickx G, et al. Towards assessing finescale indicators for the spatial transmission risk of Fasciola hepatica in cattle. Geospatial Health 2011; 5:239-45.

3. Relf V, Good B, Hanrahan JP, McCarthy E, Forbes AB, Dewaal T. Temporal studies on Fasciola hepatica in Galba truncatula in the west of Ireland. Vet Parasitol 2011; 175:287-92.

4. Afshan K, Fortes-Lima CA, Artigas, P, Valero MA, Qayyum, M, Mas-Coma S. Impact of climate change and man-made irrigation systems on the transmission risk, long-term trend and seasonality of human and animal fascioliasis in Pakistan. Geospatial Health 2014; 8:317-334.

5. Ashrafi K, Bargues MD, O’Neill S, Mas-Coma S. Fascioliasis: a worldwide parasitic disease of importance in travel medicine. Travel Med Infect Dis 2014; 12:636-649. 6. Kuerpick B, Conraths FJ, Staubach C, Frohlich A, Schnieder T, Strube C. Seroprevalence and GIS-supported risk factor analysis of Fasciola bepatica infections in dairy herds in Germany. Parasitol 2013; 140:1051-60.

7. Petros A, Kebede A, Wolde A. Prevalence and economic significance of bovine fascioliasis in Nekemte municipal abattoir. J Vet Med Anim Health 2013; 5:202205.

8. Mas-Coma S, Bargues MD, Valero MA. Diagnosis of human fascioliasis by stool and blood techniques: update for the present global scenario. Parasitol 2014; 141:1918-1946.

9. Tantrawatpan C, Maleewong W, Wongkham C, Wongkham S, Intapan PM, Nakashima K. Characterisation of Fasciola gigantica adult $27-\mathrm{kDa}$ excretory-secretory antigen in human fascioliasis. Parasitol Res 2003; 91:325327.

10. Marcos L, Maco V, Terashima A, Samalvides F, Espinoza JR, Gotuzzo E. Fascioliasis in relatives of patients with Fasciola hepatica infection in Peru. Revista do Instituto de Medicina Tropical de São Paulo 2005; 47:219-222.

11. WHO. Control of foodborne trematode infections. Report of a WHO Study Group. World Health Organization Technical Report Series 1995; 849:1-157.
12. Ashrafi K, Mas-Coma S. Fasciola gigantica transmission in the zoonotic fascioliasis endemic lowlands of Guilan, Iran: experimental assessment. Vet Parasitol 2014; 205:96-106.

13. Ashrafi K, Valero MA, Peixoto RV, Artigas P, Panova M, Mas-Coma S. Distribution of Fasciola hepatica and F. gigantica in the endemic area of Guilan, Iran: relationships between zonal overlap and phenotypic traits. Infect Genet and Evol 2015; 31: 95-109.

14. Ramachandran J, Ajjampur SSR, Chandramoham A, Varghese GM. Cases of human fascioliasis in India: tip of the iceberg. J Postgrad Med 2012; 58:150-152.

15. De NV, Hoa LT, Waikagul J. Plant-borne trematode (fascioliasis) in Vietnam. In: V Seminar on Food and Water-borne Parasitic Zoonoses (5thFBPZ) Miracle Grand Convention Hotel, Bangkok, 2006; 28-30.

16. Le TH, De NV, Agatsuma T, Nguyen TGT, Nguyen QD, McManus DP, Blair D. Human fascioliasis and the presence of hybrid/introgressed forms of Fasciola hepatica and Fasciola gigantica in Vietnam. Int J Parasitol 2008; 38:725-730.

17. Qureshi AW, Tanveer A, Qureshi SW, Maqbool A, Gill TJ, Ali SA. Epidemiology of human fascioliasis in rural areas of Lahore. Pak. Punjab Uni J Zool 2005; 20:159-168.

18. Qureshi AW, Tanveer A. Seroprevalence of fascioliasis in buffaloes and humans in some areas of Punjab, Pakistan. Pak J Sci 2009; 61: 91-96.

19. Asma WQ, Tanveer A, Mas-Coma S. Epidemiological analysis of human fascioliasis in northeastern Punjab, Pakistan. Acta Tropica 2016; 156:157-164.

20. Barbabosa IM, Quiroz MG, Cabello RR, González LR, Elena M, Cárdenas G, Sosa AA, Lastra R de JP. Seroepidemiology of fascioliasis in school children in Mexico City. Revista Biomédica 2006; 17:251-257.

21. Kheirandish F, Kayedi MH, Ezatpour B, Anbari K, Rouzbahani HRK, Sharafi AC, Zendehdel A, Bizhani, N, Rokni MB. Seroprevalence of Human Fascioliasis in Pirabad, Lorestan Province, Western Iran. Iranian J Parasitol 2016; 11:24-29.

22. Cengiz ZT, Yılmaz H, Dülger AC, Akdeniz H, Karahocagil MK, Çiçek M. Seroprevalence of human fascioliasis in Van province, Turkey. Turk J Gastroenterol 2015; 26:259-62.

23. Zumaquero-Rios JL, Sarracent-Perez J, Rojas-Garcia R, Rojas-Rivero L, Martinez-Tovilla Y, Valero MA, Mas-Coma S. Fascioliasis and intestinal parasitoses 
affecting schoolchildren in Atlixco, Puebla State, Mexico: epidemiology and treatment with nitazoxanide. PLoS Negl Trop Dis 2013; 7(11):1-16.

24. Saba R, Korkmaz M, Inan D, Mamikoğlu L, Turhan Ö, Günseren F, ... \& Kabaalioğlu A. Human fascioliasis. Clinical Microbiology and Infection 2004; 10(5): 385-387.

25. Kamel HH, Sarhan RM, Saad GA. Biochemical assessment of oxidative status versus liver enzymes in patients with chronic fascioliasis. Journal of Parasitic Diseases 2015; 39(4): 628-633.

26. Kolodziejczyk L, Siemieniuk E, Skrzydlewska E. (2005). Antioxidant potential of rat liver in experimental infection with Fasciola hepatica. Parasitology Research 2005; 96(6): 367-372.

27. Rubel D, Prepelitchi L, Kleiman F, Carnevale S, Wisnivesky-Colli, C. (2005). Study of the focus in a case of human fasciolosis in Neuquén. Medicine (Buenos Aires), 2005; 65(3): 207-212.

28. Kaya M, Beştaş R, Çetin S. Clinical presentation and management of Fasciola hepatica infection: single-cen- ter experience. World Journal of Gastroenterology 2011; 17(44): 4899.

29. Bektaş M, Dökmeci A, Cinar K, Halici I, Oztas E, Karayalcin S, ... Ormeci N. Endoscopic management of biliary parasitic diseases. Digestive diseases and sciences 2010; 55(5): 1472-1478.

30. Lipsky MS, Sadovsky R. Elevated liver enzymes. In: Lipsky MS, Sadovsky R, eds. Gastrointestinal problems Philadelphia: Lippincott, Williams and Wilkins, 2000: 55-79.

31. Kathleen M, Botham, Petar A. Cholesrol synthesis, transport and excretion. In Harpers illustrated biochemistry. Medical publishing Division. $27^{\text {th }}$ ed. The Mc Graw-Hill Companies. United State of America. 2006, pp.230-40.

32. Maco V, Marcos L, Montenegro J, Bellido J, Terashima A, Gotuzzo E. Obstruction of kehr drain due to Fasciola hepatica in a post-cholecystectomized patient secondary to acute cholangitis. Parasitol Latinoam 2003; 58: 152-158. 